Ecclesia. Studia z Dziejów Wielkopolski t. 13 (2018)

doi: 10.14746/e.2018.13.3

PAWEŁ ZAJĄC

Uniwersytet im. Adama Mickiewicza w Poznaniu

Wydział Teologiczny

\title{
Wokół planów organizacji domu księży emerytów w pocysterskim klasztorze w Obrze (1836-1906)
}

Opisując uposażenie parafii obrzańskiej i wybrane aspekty działalności duszpasterskiej w Obrze w latach 1836-1861 ${ }^{1}$, zasygnalizowałem niezrealizowane wówczas plany władz kościelnych w Poznaniu, aby w pocysterskim klasztorze w Obrze zorganizować dom księży emerytów. Już w marcu 1836 r., a więc zaledwie trzy miesiące po kasacie klasztoru cysterskiego, opracowano w Poznaniu Ustawy dla Instytutu Emerytów majacego bydź urzadzonym w Klasztorze XX. Cystersów w Obrze Powiatu Babimojskiego ${ }^{2}$. Brudnopis nosił datę 27 marca 1836 r., czystopis zaś 31 marca. Ustawy zostały zakomunikowane 9 kwietnia tegoż roku Królewskiemu Naczelnemu Prezydium Prowincji Poznańskiej³.

W niniejszym artykule zamierzam zreferować szerzej najważniejsze założenia organizacyjne projektowanego domu dla księży emerytów w Obrze, a także najistotniejsze kwestie związane z jego finansowaniem. To najprawdopodobniej ten aspekt planowanej instytucji zaważył na znacznym odroczeniu w czasie jej powstania. Choć Ustawy dla Instytutu Emerytów w Obrze przez kolejne dekady pozostały jedynie postulatem, warto zwrócić uwagę zarówno na ich treść, jak też na założenia budżetowe im towarzyszące. Wpisują się bowiem $\mathrm{w}$ wielowiekową tradycję troski o emerytowanych kapłanów w diecezji

${ }^{1}$ Zob. Uposażenie parafii obrzańskiej $i$ wybrane aspekty działalności duszpasterskiej w okresie pocysterskim w latach 1836-1861, „Ecclesia. Studia z Dziejów Wielkopolski” 8 (2013), s. 167-205.

${ }^{2}$ Ustawy dla Instytutu Emerytów mającego bydź urządzonym w Klasztorze XX. Cystersów $w$ Obrze Powiatu Babimojskiego, Archiwum Archidiecezjalne w Poznaniu (dalej AAP), Akta Arcybiskupie - Księża Emeryci i demeryci: urządzenie domu dla nich, 1835-1866, sygn. OA VI 004, k. 81r-84v. Czystopis w wersji polsko-niemieckiej, OA VI 004, k. 115r-121v.

${ }^{3}$ Ks. Brzeziński do abpa Przyłuskiego, 19.11.1847, AAP, OA VI 004, k. 181. 
poznańskiej oraz dają wgląd w życie codzienne duchownych w Wielkopolsce 1. połowy XIX wieku, stanowiąc ważny przyczynek do poznania sytuacji ekonomicznej regionu.

\section{Inicjatywa abpa Marcina Dunina na tle tradycji diecezji poznańskiej}

Co do owej tradycji, jak pisał ks. Józef Nowacki, ,nawet skromnie udotowane beneficjum parafialne utrzymać mogło plebana starca lub schorzałego i jego zastępcę, wikariusza, albo zapewnić mu dekretem biskupa emeryturę, gorzej przedstawiał się los schorzałych altarzystów i wikariuszy lub księży z własnej winy wytrąconych ze stanowisk kapłańskich"4. Historyk wskazywał następnie na pomoc, jakiej tacy kapłani mogli szukać w konfraterniach kapłańskich lub w szpitalach dla starszych i chorych księży, które już od początku XV w. działały w Poznaniu. Kwestie te podejmowały synody diecezji poznańskiej w XVII i XVIII w., zachęcając do przekazywania datków pieniężnych w rozmaitej formie na rzecz hospicjów dla księży. Jednak - jak podsumowuje ks. Nowacki - „nie stworzono żadnego stałego funduszu, który by w dostatecznej mierze zabezpieczył los księży chorych i starców, a ułatwiał beneficjantom sędziwym i zniedołężniałym dla dobra Kościoła zrzeczenie się zajmowanych stanowisk i przejście na emeryturę"5. Przełomem mogły być postanowienia bulli De salute animarum z 1821 r., zgodnie z którą obowiązek finansowania w podobnych przypadkach przechodził na państwo, z racji przejęcia przez nie kościelnych gruntów i obiektów. Ksiądz Nowacki jednak błędnie konkluduje, iż po długich rokowaniach dom księży emerytów powstał w 1834 r. w Obrze $^{6}$. Rokowania rzeczywiście były długie, lecz przeciągnęły się znacznie poza wskazaną datę.

Działania arcybiskupa Marcina Dunina na rzecz odpowiedniego wykorzystania pocysterskich zabudowań w Obrze wpisywały się w cały szereg jego decyzji zmierzających do stabilizacji sytuacji kościelnej w Wielkopolsce. Parafie i inne kościelne instytucje dotkliwie odczuwały skutki rozbiorów, kasat oraz włączenia w pruski system fiskalny. Z uwagi na uwarunkowania polityczne w Wielkim Księstwie Poznańskim i wzmożoną politykę germanizacyjną po objęciu funkcji naczelnego prezesa Księstwa przez Eduarda Heinricha Flottwella $^{7}$, działania hierarchy nie zawsze kończyły się powodzeniem. Pisano

4 J. Nowacki, Archidiecezja poznańska w granicach historycznych i jej ustrój, t. 2, Poznań 1964, s. 735.

5 Tamże, s. 736.

6 Tamże.

7 Zob. F. Paprocki, Wielkie Księstwo Poznańskie w okresie rządów Flottwella, 1830-1841, Poznań 1994, s. 67n. 
już o jego planach przywrócenia choćby części klasztorów w obu archidiecezjach $^{8}$, czy o zaangażowaniu na rzecz katolickich instytucji oświatowych - liceum teologicznego i seminarium duchownego w Poznaniu9. Ksiądz Władysław Hozakowski konkludował swój artykuł na temat liceum - które ostatecznie nie powstało na skutek sprzeciwu władz pruskich - słowami: „W walce tedy o liceum teologiczne w Poznaniu, prowadzonej przez arcybiskupa Dunina przeciw germanizującym zamysłom naczelnego prezesa Flotwella, zwyciężył chwilowo Flotwell" ${ }^{10}$. W przypadku domu księży emerytów w Obrze na razie także skończyło się na projekcie, a wśród wielu przyczyn odroczenia jego realizacji do głównych zaliczyć wypada przede wszystkim trudne do rozwiązania kwestie odpowiedniego finansowania zakładu.

Jak wspomniano, deklaracja współpracy władz kościelnych z rządem pruskim w kwestii finansowania domów dla księży emerytów została zawarta w bulli Piusa VII De salute animarum:

$\mathrm{Na}$ wspomnianego Biskupa Józefa [Hohenzollerna] ${ }^{11}$ nakładamy obowiązek, by każdy Sufraganat Arcybiskupi i Biskupi posiadał wystarczającą dotację, by wszystkim Arcybiskupom i Biskupom wystarczało na zatrudnienie Wikariuszy Generalnych i Kurii oraz na utrzymanie urzędników, co jest zgodnie z uprzejmym zarządzeniem Króla Pruskiego. Jako że Najjaśniejszy Król Pruski obiecał Nam, iż dopomoże do remontów tych domów, w których przebywali emerytowani względnie chorzy duchowni, także ci niezdyscyplinowani, których wybryki należało powstrzymać, jak również obiecał, że pomoże budować nowe, gdzie ich braknie, $\mathrm{z}$ tego też względu polecamy Biskupowi Józefowi, by zapoznał się z tym, co już przedsięwziął przesławny Król i po wysłuchaniu zainteresowanych Biskupów diecezjalnych, pod których jurysdykcją te domy mają pozostawać, by zarządził wszystko, co konieczne do ich udotowania ${ }^{12}$.

Rzeczywistość okazała się bardziej skomplikowana. Nad etatem (tj. budżetem) planowanej instytucji opiekuńczej dla księży w Obrze dyskutowano

${ }^{8}$ P.F. Neumann, Starania arcybiskupa Marcina Dunina i Edwarda Raczyńskiego o przywrócenie klasztorów w archidiecezjach gnieźnieńskiej i poznańskiej, „Ecclesia. Studia z Dziejów Wielkopolski" 2 (2006), s. 221-247.

${ }^{9}$ Zob. J. Nowacki, L. Piechnik, W. Hozakowski, Dzieje Seminarium Duchownego w Poznaniu w latach 1564-1939, Poznań 2006; W. Hozakowski, Arcybiskup Dunin a Liceum Teologiczne, „Kronika Miasta Poznania” 1923, nr 12, s. 222-236.

${ }^{10}$ Tamże, s. 236.

${ }^{11}$ Bp warmiński Józef Hohenzollern (1776-1836) został mianowany przez Piusa VII delegatem apostolskim dla realizacji postanowień bulli. Wykonawcą tych postanowień ze swej strony uczynił go także król Fryderyk Wilhelm III. Zob. A. Kopiczko, Reorganizacja Kościoła katolickiego w Prusach na podstawie bulli „De salute animarum”, „Kościół w Polsce. Dzieje i Kultura” 12 (2013), s. 71 .

${ }^{12}$ Cyt. za: M. Józefczyk, Translacja bulli „De salute animarum” i dokumentów korygujacych granice diecezji warmińskiej w 1861 i 1922 roku, ,Studia Elbląskie” 18 (2017), s. 25. 
jeszcze długo po śmierci abpa Dunina, choć w 1836 r. arcybiskup gnieźnieński i poznański w preambule Ustaw stwierdzał rzecz pozornie oczywistą - to z kasy rządowej miały płynąć środki na utrzymanie księży, „którzy dla choroby lub podeszłego wieku, do dobywania posług duchownych i zarządu nad beneficjum stali się niezdolnymi”. Zakładano, że będzie ich w Obrze docelowo dwudziestu ${ }^{13}$. Rząd miał obowiązek otoczyć instytut opieką ekonomiczną, natomiast codzienny nadzór nad jej funkcjonowaniem należałby w pełni do arcybiskupa, który w tym celu mianował ,duchownego inspektora”, z odpowiedzialnością tak za materialną, jak i duchowną stronę funkcjonowania instytucji (§ 2 $)^{14}$. Infrastruktura obejmowała klasztor obrzański, z przyległym ogrodem i dwiema łąkami $(\S 3)^{15}$. Budżet domu emerytów miał być aktualizowany co trzy lata - pierwszy tego rodzaju dokument przygotowano wraz z Ustawami, obejmując planowaniem lata $1836-1838^{16}$. Wszystkie wydatki miały być stosownie dokumentowane, a ewentualne przekroczenie budżetu wymagało pozwolenia arcybiskupa ${ }^{17}$.

\section{Ustawy dla Instytutu Emerytów w Obrze}

Zanim przejdę do podstawowych uwag na temat budżetu, jakie doradcy arcybiskupa zgłaszali w kolejnych latach, warto przyjrzeć się poszczególnym punktom Ustaw, opisujących ogólnie zasady wspólnego życia kapłanów w planowanej instytucji. Pierwsza część tego zbioru praw życia codziennego dotyczyła obowiązków duszpasterskich, życia duchowego i wzajemnych braterskich relacji. Księża emeryci mieli być zwolnieni z obowiązków duszpasterskich, zostali jednak zaproszeni, by wspierać miejscowego proboszcza w czasie spowiedzi wielkanocnej czy podczas odpustów, by w ten sposób oddziaływać na młodszych księży dobrym przykładem $(\S 6)^{18}$. W Wielkim Tygo-

13 „Koszta utrzymywania tego instytutu opłacane będą z kasy rządowej, do których należą także i one emerytalne pensje, które dotychczas wysłużeni kapłani bezpośrednio pobierali, a na ich miejsce będą mieli odtąd pomieszczenie i utrzymanie, aż do śmierci, w mającym się urządzić instytucie". Ustawy, k. 81r.

14 Tamże, 81v.

15 Tamże.

16 AAP, Akta Arcybiskupie - Księża Emeryci i demeryci: urządzenie domu dla nich, 1835-1866, sygn. OA VI 004, k. 64r-73r.

17 ,Inspektor będzie utrzymywał staranny dziennik roczny wszelkich przychodów i wydatków i w tem ma zapisywać każdy wydatek stosownie do potwierdzonego etatu, a na końcu roku ułoży rachunki, które wraz z dowodami najpóźniej do ostatniego marca Arcybiskupowi przedłożyć winien. Wydatków nad etat czynić nie jest mocen, gdyby jednak takowe koniecznie potrzebne były, powinien wprzód na to zezwolenie Arcybiskupa uzyskać". Ustawy, k. 81v.

18 Tamże, k. 82r. 
dniu mieli odprawiać doroczne wspólnotowe rekolekcje. Zalecaną lekturą na ten czas były pisma Karola Boromeusza, a więc dzieła o charakterze wybitnie duszpasterskim $(\S 7)^{19}$. Środkiem do utrzymania harmonii i spokoju oraz dobrych relacji pomiędzy księżmi miały być comiesięczne spotkania, podczas których należało omawiać sprawy sporne czy niepokojące. Autor Ustaw zachęcał, by ewentualne nieporozumienia rozwiązywać na bieżąco. Jedynie najtrudniejsze sprawy i konflikty trzeba było przedstawiać samemu arcybiskupowi lub jego konsystorzowi $(\S 8-9)^{20}$.

Kolejne punkty dotyczyły swobodnego wychodzenia z klasztoru oraz przyjmowania gości $(\S 10)^{21}$, a także dobrego zachowania $(\S 11)^{22}$. U zacnych i doświadczonych kapłanów zakładano odpowiedni poziom kultury osobistej, a jednak proponowano także, by inspektor nadzorował zachowanie indywidualnych pensjonariuszy i sporządzał na ten temat coroczny indywidualny raport, do wiadomości samego arcybiskupa. Wreszcie podejmowano kwestię ewentualnych spadków na rzecz instytutu oraz regulacji finansowych związanych z pogrzebem $(\S 12)^{23}$.

Dalsze paragrafy Ustaw dotyczyły spraw coraz bardziej praktycznych, zatem warto je zestawić w całości, gdyż stanowią faktyczny „regulamin” życia codziennego:

$\S 13$. Ażeby zdatnym jeszcze do pracy członkom instytutu podać sposobność do zatrudnienia, wolno będzie inspektorowi podług dowolnego upodobania różne części i przedmioty zarządu domowego podzielać pomiędzy tychże członków, i tak może bydź powierzony pod nadzorem inspektora: a) jednemu dozór nad kuchnią, b) drugiemu nad ogrodem, itd.

${ }^{19}$ Tamże.

${ }^{20}$ Tamże, k. 82v. Autor Ustaw stwierdzał w paragrafie 8: „Ponieważ celem tego instytutu jest zabezpieczenie członkom jego wspólnego spokojnego i wygodnego życia, przeto starać się powinni emeryci, ażeby z sobą w zgodzie i miłości braterskiej żyli, tym więcej, im bardziej się do grobu i końca swego zbliżają".

21 „Członkowie instytutu nie są obowiązani do klauzury, mogą przeto podług upodobania we dnie o każdej godzinie wychodzić, nie mniej przyzwoite i niepodejrzane wizyty przyjmować, jeżeli tak przez pierwsze, jako i drugie ani dobry porządek, ani przepisy instytutu nadwyrężone nie będą. Jeżeli zaś który z członków ma zamiar gdziekolwiek wyjechać, albo gdzie indziej przenocować, na obiedzie lub kolacji nie znajdować się, winien o tem w każdym razie inspektora wcześnie zawiadomić". Tamże, k. 82v.

22 „Lubo spodziewać się należy, że członkowie instytutu pamiętni na godność swojego stanu zawsze się przyzwoicie zachowywać będą, pomimo tego jednak winien inspektor utrzymywać listę ich konduity, którą przy końcu każdego roku w jednym egzemplarzu Arcybiskupowi, w drugim jego Jeneralnemu Konsystorzowi prześle". Tamże.

23 „Jeżeli emeryt nie ma ani bliskich, ani dalekich krewnych, może swój majątek na dobro instytutu zapisać, który go po śmierci właściciela zabierze. Po zgonie każdego członka nastąpi opieczętowanie jego pozostałości, do czego sądową osobę przybierać należy. Pogrzeb ma się odprawiać na koszt instytutu". Tamże. 
$\S 14$. Dom instytutu otwierany będzie od 1 listopada do Wielkiej nocy o siódmej godzinie z rana, a zamykany o 9 wieczorem. Od Wielkiej nocy zaś do 1 listopada otwierany będzie o godzinie $5 \mathrm{z}$ rana, a zamykany na wieczór o godzinie 10 .

$\S 15$. W ciągu całego roku będą emeryci za danem znakiem dzwonka, chodzili do wspólnego stołu na obiad o 12 godzinie w południe, a na kolacją o 6 wieczorem. Przed każdem zaś jedzeniem mówić będą przepisane w brewiarzu do tego stosowne modlitwy.

$\S 16$. Żadnemu członkowi instytutu nie jest zabronionem nie znajdować się na obiedzie lub kolacyi, przecież winien o tem inspektora lub jego zastępcę wcześnie uwiadomić. Za takie przecież opuszczone obiady lub kolacje żadne wynagrodzenie z kasy instytutu emerytowi dawane nie będzie.

$\S 17$. Żadnemu emerytowi nie jest wolno kazać sobie do stancyi jedzenie przynosić, wyjąwszy tylko przypadek choroby, która mu nie dozwoli do wspólnego stołu chodzić, lub w ten czas kiedy to doktor, za rzecz potrzebną osądzi. [83v] W każdym podobnym przypadku powinien inspektor o tem bydź uwiadomiony.

$\S 18$. Ponieważ trafić się może przypadek, że członka instytutu będzie chciał który z krewnych lub dobrych przyjaciół odwiedzić i tego życzyłby sobie emeryt do stołu wspólnego zaprosić, przeto dla wygody emerytów wolno im to będzie czynić, jeżeli inspektor wcześnie o tem uwiadomiony zostanie. Za każdą przecież osobę musi bydź od kasy instytutu 5 [groszy?] zapłacone.

$\S 19$. Na obiad w dni mięsne miewać będą emeryci rosół, wołową lub inną sztukę mięsa, jarzynę stosowną do pory roku i pieczeń, w dni zaś postne, zupę mleczną, ryby, jaja, jarzynę z masłem. Na kolacją zaś zupę i potrawę, kartofle z masłem albo z śledziem. Wybór i odmiana tych potraw zostawia się zupełnie inspektorowi, byle tylko przez to wydatki etatem przepisane powiększone nie były. Wino dawane tylko będzie chorym i słabym emerytom, według zachodzących okoliczności. Piwo zaś stawiane będzie do obiadu i kolacyi na stole, z którego każdy członek do woli pić może. Nad trzy kwarty nie wolno przecież na dzień dla jednego wydawać. Chleba będzie każdemu członkowi tyle dano ile go spotrzebuje. Na śniadanie dawana będzie podług okoliczności albo porcja kawy z mlekiem i cukrem, albo grzane piwo z masłem.

$\S 20$. Od Wszystkich Świętych, czyli od 1 listopada aż do 1 [84r] kwietnia ma bydź w stancyi każdego emeryta po dwa razy na dzień w piecu palone, przytem jednak na zmiany powietrza uważać należy.

$\S 21$. Każdy emeryt dostanie do swojej stancyi potrzebną ilość świec, oprócz tego zaś w czasie wieczorów zimowych oświecana będzie jedna sala do wspólnego gromadzenia się i zabawy, podobnież korytarze oświecane będą świecami albo lampami.

$\S 22$. W czasie choroby emeryta kasa instytutu ponosić będzie koszta doktora i apteki.

$\S 23$. Do stancyi dla emerytów przeznaczonych sprawione będą z kasy instytutu łóżka, stoliki, krzesełka, szafy itd. Dla instytutu zaś stołowe potrzeby, obrusy, serwety, talerze, łyżki, noże, widelce, szklanki, solniczki, itd. 
$\S 24$. Ponieważ każdy członek wstępując do instytutu pospolicie przynosi $\mathrm{z}$ sobą potrzebny ubiór, przeto w ten czas dopiero, gdy ten nieużytecznym się stanie, będzie mu nowy co dwa lata na koszt instytutu sprawiany, stary zaś pozostanie się dla instytutu, który inspektor z wolnej ręki, albo przez publiczną licytacją sprzeda i pieniądze zań zabrane do kasy instytutu weźmie.

$\S 25$. Produkta ogrodu obracane będą o ile wystarczą, na potrzeby instytutu, zbywające zaś mają bydź [84v] sprzedawane, pieniądze za to zebrane do kasy instytutu zapisane. Ogród służyć ma także do rekreacyi dla emerytów, z których każdy starać się zapewne będzie o jego ulepszenie, a nie dozwoli, aby przez kogo, a tem bardziej przez niego samego miał bydź niszczony ${ }^{24}$.

Podsumowując przedstawione wyżej zasady, warto zwrócić uwagę na ich praktyczny charakter, przypominający regulaminy kościelnych instytucji wychowawczych. Mieszkając w murach pocysterskiego klasztoru, księża emeryci stylem życia de facto przypominaliby wspólnotę zakonną. W ten sposób negatywne skutki kasaty byłyby choć odrobinę zmniejszone, kościelna infrastruktura nie byłaby narażona na zniszczenie, przy regularnych nakładach finansowych państwa na jej utrzymanie.

\section{Kapłańskie dyskusje nad ideą domu księży emerytów}

Projekt utworzenia w Obrze domu dla księży emerytów z pewnością odbił się szerokim echem wśród księży archidiecezji gnieźnieńskiej i poznańskiej. Jeszcze 23 marca swoje uwagi w tej materii przekazał arcybiskupowi Duninowi dziekan foralny poznański, kanonik kolegiaty św. Marii Magdaleny i pleban winnogórski, Dionizy Musielski ${ }^{25}$. Deklarując najwyższy szacunek wobec swego pasterza, jednocześnie powoływał się na swe długie doświadczenie w materii troski dotyczącej „ogólnego losu na starość wszystkiego duchowieństwa, które szczerze i sumiennie swoje zdrowie, siły i życie poświęca pracy w zawodzie apostolskim"26. Zabranie głosu uważał za swój obowiązek, ponieważ - jak stwierdził - to właśnie kapituły metropolitalne oraz dziekani foralni, zastępujący dawnych archidiakonów, powinni doradzać oraz być z urzędu „oczami biskupów” (oculi episcoporum), czyli w tym przypadku arcybiskupa gnieźnieńskiego i poznańskiego, „który przez ich oczy wszystko to, co się na Archidiecezji dzieje, słyszy i widzi" ${ }^{27}$. W swoim memoriale dziekan dziękował najpierw arcybiskupowi za podjęcie w rozmowach z królem

\footnotetext{
${ }^{24}$ Tamże, k. 83r-84v.

${ }^{25}$ Ks. Musielski do abpa Dunina, 23.03.1836, AAP, OA VI 004, k. 91r-v, 96r.

${ }^{26}$ Tamże, k. 91 r.

${ }^{27}$ Tamże, k. 91r-v.
} 
i rządem pruskim kwestii księży emerytów, zgodnie z treścią bulli De salute animarum $^{28}$. Zdaniem kanonika definitywne rozwiązanie kwestii finansowania instytucji domu emerytów było zagadnieniem kluczowym. W kontekście powszechnego kryzysu finansów Kościoła, w związku z polityką pruską wobec kościelnych dóbr i beneficjów, państwowe subwencje dla domu emerytów były niezbędne. Musiały one być zagwarantowane w taki sposób, by ogólny budżet mógł być w przyszłości korygowany, według nieprzewidywalnych obecnie wydatków i kosztów utrzymania księży emerytów.

Inną sprawą był wybór miejsca takiej instytucji, ,aby się ku domowi takiemu powszechny wstręt nie zawiązał i ten w przyszłości szkodliwego wpływu nie wywierał na stan cały"29. Choć memoriał dziekana nie zawierał bezpośredniej polemiki z planem osadzenia instytucji domu księży emerytów w Obrze, a więc na wsi, daleko od Poznania, kapłan jednak uczynił wszystko, by przekazać arcybiskupowi argumenty na korzyść większego miasta. Musielski powołał się na przykład bpa Krzysztofa Antoniego Szembeka i zwołanego przezeń synodu diecezji poznańskiej z $1720 \mathrm{r}^{30}$, który postanawiał wsparcie materialne dla dwóch fundacji - w Poznaniu, przy kościele św. Wawrzyńca na Chwaliszewie ${ }^{31}$ oraz w Łowiczu ${ }^{32}$. Podobnie postępowali władcy świeccy, troszcząc się o swych poddanych, którzy całe życie wiernie służyli państwu (przykład Poczdamu k. Berlina). Biskupi i arcybiskupi także umieli poświęcać uwagę kapłanom w podeszłym wieku - i tu puenta księdza kanonika była

${ }^{28}$ Zob. Rzut oka na stosunki zachodzące przy zakładaniu Instytutu XX. Emerytów i Inwalidów dla Archidiecezji Poznańskiej [autor: ks. Dionizy Musielski], OA VI 004, k. 92r-95v.

${ }^{29}$ Tamże, k. 92r.

${ }^{30}$ Zob. Synodus dioecesana posnaniensis sub Illustrissimo ac Reverendissimo Domino D. Christophoro Szembek, Dei et Apostolicae Sedis Gratia Episcopo Posnaniensi, nominato Vladislaviensi, Abbate Commendatario Clare Turbae per biduum Varsaviae in Insigni Ecclesia Collegiata S. Joannis Baptistae Celebrata A.D. MDCCXX Diebus 27 et 28 Mensis Februarii, Varsaviae, Typis S.R.M. Scholarum Piarum. Rozdział XXVI akt synodalnych nosił tytuł De hospitalibus sacerdotum pauperum, infirmorum, emeritorum, ac beneficiis carentium et de derelictis ab intestato. Zob. J. Sawicki, Synody diecezji poznańskiej i ich statuty, Poznań 1952, s. 109-118; J. Nowacki, Synody diecezji poznańskiej w latach 1252-1738, Poznań 2004, s. 106-115.

${ }^{31}$ Jak pisał ks. Nowacki: „Pierwszą o nim wzmiankę zauważyliśmy pod koniec 1509 r. [...] Biskup Andrzej Szołdrski udotował hojnie szpital i przeznaczył go 1642 dla 'ubogich księży', tj. ubogich, chorych starców kapłanów, przywilej erekcyjny wystawił 19 VII 1652 biskup Kazimierz Florian Czartoryski. Po inkorporacji kościoła św. Wawrzyńca z r. 1805 rozebrano zrujnowany szpital w r. 1812, mienie jego wcielono do kurialnego 'Funduszu Księży Ubogich””. J. Nowacki, Archidiecezja poznańska, s. 652.

${ }^{32}$ Tak pisze kanonik Musielski, w aktach synodalnych mowa jest o miejscowości Góra i kościele Krzyża Świętego („Pro Hospitali vero Archidiaconatus Varsaviensis, quod erit in Oppido Gorae, ad Ecclesiam S. Crucis [...]”) - chodzi tu zapewne o Górę Kalwarię, w której znajdował się kościół Podwyższenia Krzyża Świętego oraz „,dom przytułku na 150 osób, szpital przy domu przytułku na 5 łóżek". Zob. Stownik geograficzny Królestwa Polskiego i innych krajów stowiańskich, red. F. Sulimierski, B. Chlebowski, W. Walewski, t. II, Warszawa 1881, s. 689. 
jednoznaczna: „Zakładali Instytuta owe, nie w oddaleniu żadnem od miast, nie w miejscach odludnych po wsiach, jako mniej interesowane Instytuta, ale pod bokiem i bezpośrednim prawie swem opiekuńczem okiem na miejscach własnych rezydencjonalnych dla bardzo ważnych i pożytecznych widoków ich władzy nawet, którą piastują"33. Argumenty na korzyść miasta wynikały z „ludzkości, przyzwoitości i słuszności”’34, ale także ze względów praktycznych: miasto ułatwiało opiekę nad starszymi i chorymi. Przechodząc do kwestii praktycznych, a więc wskazania możliwych do zaadaptowania na taki cel gmachów w Poznaniu, autor memoriału wymieniał budynki klasztorne oo. bernardynów, dominikanów albo sióstr karmelitanek, bądź grunty księży filipinów na Śródce (księża emeryci mieszkali już przy tamtejszym kościele św. Małgorzaty ok. 1810 r. $)^{35}$.

Kwestią otwartą pozostaje, czy odezwa ks. Musielskiego była głosem odosobnionym, czy też z podobnymi memoriałami zwróciło się do arcybiskupa więcej kapłanów. Szersze konsultacje wokół domu księży emerytów wykazały dość dużą rozbieżność zdań co do planów jego lokalizacji, uposażenia czy wręcz samej zasadności tworzenia takiej instytucji, o czym będzie mowa jeszcze niżej.

28 września 1842 r., a więc na kilka miesięcy przed swą śmiercią, arcybiskup skierował do duchowieństwa archidiecezji gnieźnieńskiej i poznańskiej pytanie zasadnicze. Chciał uzyskać opinię, czy właściwą jest decyzja utworzenia jednego domu księży emerytów dla obu archidiecezji, czy też należałoby pomyśleć o oddzielnych domach?

W imieniu kapituły metropolitalnej gnieźnieńskiej 3 listopada odpowiedział Leon Przyłuski ${ }^{36}$. Referując refleksję kanoników gnieźnieńskich, podkreślił, iż kapłani starali się najpierw odpowiedzieć na pytanie, czy wspólne życie i jego wymagania są do pogodzenia $\mathrm{z}$ utrapieniami starszego wieku. Ich konkluzja była jednoznaczna: „niedołężna starość nie kwalifikuje się już do komunalnego życia"37. Wspólne życie zdaniem Przyłuskiego i kanoników gnieźnieńskich zakładać musi regularność planu dnia (spoczynek, wstawanie, modlitwy, posiłki, ta sama dieta itp.). Tymczasem starość domaga się nieraz spożywania posiłku nocą, osobnej diety. Zagwarantowanie takiego indywidualnego traktowania w instytucji, jaką miał być dom księży emerytów, znacznie podwyższyłoby koszty jej utrzymania. Zatem z Gniezna popłynęła sugestia,

\footnotetext{
${ }^{33}$ Rzut oka na stosunki zachodzące przy zakładaniu Instytutu XX. Emerytów, k. 93r.

${ }^{34}$ Tamże, k. 94r.

${ }^{35}$ Tamże, 95r-v. Ks. Nowacki odnotowuje istnienie szpitala przy kościele św. Małgorzaty, lecz nie podaje żadnych danych dla przełomu XVIII i XIX w. Zob. J. Nowacki, Archidiecezja poznańska,

${ }^{36}$ Ks. Przyłuski do abpa Dunina, 3.11.1842, AAP, OA VI 004, k. 129r-v, 132r.

${ }^{37}$ Tamże, k. 129r.
} s. 652. 
by zaniechać idei tworzenia instytucji przeznaczonej dla grupy starszych kapłanów.

Odpowiedź kapituły poznańskiej była odmienna. Kanonicy poznańscy opowiadali się za koniecznością utworzenia wspólnego domu dla księży emerytów: ,tego wymaga stan i godność kapłana, tego i szacunek u publiczności, aby spracowany i obciążony wiekiem, w towarzyszących starości słabościach i cierpieniach, znalazł przytułek i porękę, w miejscu przyzwoitym, i nie był zmuszony, albo stać się ciężarem innym, albo być wystawionym na jakową ohydę" ${ }^{38}$. Dostrzegano ryzyko, że przy braku wystarczającej liczby księży emerytów, w naturalny sposób do tego rodzaju instytucji będą kierowani demeryci, co całkowicie zniszczyłoby jej obraz i leżącą u podstaw szczytną ideę wsparcia zasłużonych duszpasterzy. Należało więc pilnować odrębności instytucji - dla księży emerytów i demerytów. Co do lokalizacji proponowano wynajęcie pomieszczeń w zabudowaniach kongregacji księży filipinów w Gostyniu lub zaadaptowanie części zakładu demerytów w Osiecznej. Drugie rozwiązanie byłoby jednak tak samo kosztowne, jak przystosowanie klasztoru w Obrze, zatem wszystko wskazywało, że lepszą propozycją był klasztor księży filipinów.

\section{Problem budżetu dla domu księży emerytów}

Do dyskusji nad zasadnością tworzenia instytucji domu księży emerytów oraz nad kwestią jego lokalizacji ks. kanonik Józef Brzeziński włączył dogłębną analizę planowanego budżetu. Pisząc swe refleksje już na polecenie abpa Leona Przyłuskiego, pod koniec lat czterdziestych XIX w., uznał budżet sprzed dekady za znacznie zaniżony ${ }^{39}$. Sprawa była o tyle niepokojąca, że jeszcze w 1837 r. abp Dunin złożył podanie do Naczelnego Prezydium o podwyższenie rocznego budżetu, lecz petycja ta pozostała bez odpowiedzi. Zadeklarowano jedynie, że sprawa została przekazana do ministerstwa ${ }^{40}$. Skoro jednak wciąż instytucja nie powstała, obecny arcybiskup powinien petycję ponowić, ponieważ korekta budżetu raz wprowadzonego w życie mogłaby się okazać znacznie trudniejsza.

Następnie ks. Brzeziński powtórzył swoje sugestie komunikowane jeszcze w latach trzydziestych abpowi Duninowi. Większość z nich miała charakter bardzo praktyczny - ksiądz kanonik sugerował, by przy domu księży emerytów zatrudnić wystarczająco liczny personel pomocniczy, przede wszyst$133 \mathrm{r}$.

${ }^{38}$ Kapituła metropolitalna do abpa Dunina, 31.10.1842, AAP, OA VI 004, k. 133r-136r, tu:

\footnotetext{
${ }^{39}$ Ks. Brzeziński do abpa Przyłuskiego, 19.11.1847, AAP, OA VI 004, k. 181r-188v.

${ }^{40}$ Tamże, k. 182r.
} 
kim kucharkę ${ }^{41}$, ogrodowego ${ }^{42}$ i szwaczkę ${ }^{43}$. Pozwolenie na zatrudnienie tego personelu, wraz z mniej wykwalifikowanymi pomocnikami, było kwestią kluczową dla planów budowy nowego pomieszczenia gospodarczego. Gdyby lista zatrudnionych została zaakceptowana, można by marzyć o budynku gospodarczym składającym się z , izby i komory dla kucharza, izby, komory i kuchni dla ogrodowego, izby dla gospodyni, izby dla dwóch dziewcząt, izby dla szwaczki, izby dla nocnego stróża, izby do robienia chleba, czyli piekarni z piecem do pieczenia, pralni z ogniskiem, rzezalni, mleczarni, góry do zachowywania nasion, owoców i ogrodowin" 44 .

O dziwo, pod koniec 1855 r. ks. Brzeziński przekazywał arcybiskupowi wciąż te same sugestie. Znacznie dokładniejszy tym razem raport poznańskiego kanonika znajduje się in extenso w poniższym aneksie. Zawiera on nie tylko ważne informacje na temat cen wielu produktów żywnościowych, części ubioru itp., ale także przypomina o braku stabilności ekonomicznej: „od roku 1836 do 1855 nadzwyczaj podniosła się cena wszystkich artykułów do żywności potrzebnych". Ponieważ ks. Brzeziński zdecydował się podać w wykazie ceny z lat trzydziestych XIX w., a więc z pierwotnego budżetu planowanego domu księży emerytów, dodawał: „Do tych cen niskich już zapewne nigdy nie przyjdzie, a ile teraźniejsze przewyższają powyższe, każdy wie, kto własny dom prowadzi”.

Omówione wyżej dyskusje ukazują trud realizacji najbardziej nawet uzasadnionego i potrzebnego projektu, jakim była idea domu księży emerytów

${ }^{41}$ „Kucharki dobrej i przytem porządnej i rządnej gospodyni trudno znaleźć w tutejszej okolicy, zwłaszcza gdy się zważy, że ta ma gotować jedzenie dla ks. emerytów, (którzy odmiennych potraw, a w razie choroby nawet wyszukańszych będą), dla przełożonego instytutu i całej usługi złożonej z 10 osób. Z resztą gospodyni mająca się trudnić wedle projektu dawnego do etatu, kuchnią, praniem bielizny dla XX. Emerytów i stołowej, szyciem, pieczeniem chleba, dozorem nad krowami, robieniem masła i sera, nie potrafiłaby tym wszystkim obowiązkom w jednej osobie zadosyć uczynić. Widoczną jest więc potrzeba osobnego kucharza, któryby śniadanie, obiad i kolację gotował, wiktuały, mięso, ryby, itd., z Wolsztyna zwoził i osobnej gospodyni, któraby resztę wyżej wskazanych prac podejmować mogła”. Tamże, k. 182r-v.

42 „Ogrodowy jest także koniecznie potrzebny, gdyż przy instytucie jest piękny, obszerny, angielski i owocowy ogród, musi się więc nim opiekować i w nim pracować znający się na sztuce ogrodowej, aby zachować w porządku ogród będący ozdobą domu. Muszą bydź także w owym ogrodzie siane i sadzone warzywa i różne ogrodowiny, bo te w Wolsztynie są bardzo drogie, a zdarzają się przypadki, że ich nawet kupić nie można". Tamże, 182v-183r.

43 „Szwaczka jest także potrzebną, bo gospodyni cały tydzień gospodarstwem zajęta, nie może mieć tyle czasu aby przytem trudzić się jeszcze mogła szyciem nowej i naprawianiem podstarzałej bielizny dla 15 księży, którzy ochędożnie i czysto winni być utrzymywani. Dziewki wiejskie, czyli posługaczki, do tej pracy nie mogą bydź też dantis używane, bo one do tego nie są zdatne, a najbliższe miasto Wolsztyn skąd by szwaczki najmowane bydź mogły, przeszło milę od Obry jest odległe. Z resztą i to na uwadze mieć wypada, że i bielizna stołowa i pościel musi bydź w porządku utrzymywana". Tamże, k. 182v.

${ }^{44}$ Tamże, $188 \mathrm{r}$. 
w pocysterskich zabudowaniach klasztornych w Obrze. Rzecz jasna, dyskusyjna była lokalizacja, a księża pytali, czy nie lepiej taki dom ulokować w stolicy archidiecezji. Niektórzy powątpiewali co do samej idei wspólnego, niemal zakonnego stylu życia dla starszych kapłanów. Najistotniejsze wydawały się jednak kwestie ekonomiczne - finansowania i rocznego budżetu instytucji, która w tym względzie była całkowicie uzależniona od dotacji państwowej. Fakt, iż przez blisko 20 lat wciąż nieuregulowane pozostawały kwestie liczby pracowników domu księży emerytów czy wydatków na tzw. victum et amictum, ukazuje realia, w jakich funkcjonował Kościół w Wielkopolsce w 1. połowie XIX wieku.

\section{Realizacja idei domu księży emerytów w Obrze w początkach XX w. - zarys problematyki}

Gdy powrócono do idei domu księży emerytów w Obrze w początkach XX w., okazało się, że trzeba przezwyciężyć jeszcze inne trudności. Otóż dawny klasztor oraz przylegające do niego ogrody i podwórza zapisane były w księdze hipotecznej na katolicką gminę kościelną w Obrze. Skoro rząd królewski decydował się przekazać je stolicy arcybiskupiej z zamiarem utworzenia w nich domu księży emerytów, należało dokonać korekty tego wpisu. 7 lipca 1904 r. Konsystorz Generalny Arcybiskupi polecał tę czynność dozorowi kościelnemu w Obrze ${ }^{45}$. Nie spotkało się to bynajmniej z natychmiastową aprobatą miejscowego proboszcza, ks. Antoniego Bresińskiego, który zwracał uwagę na niewłaściwe uszczuplenie parafialnego beneficjum ${ }^{46}$. Postanowiono więc sprawę odroczyć i na 1 września 1904 r. wyznaczono wizytę w Obrze dziekana babimojskiego, ks. Schwaba, celem dokonania właściwego rozgraniczenia gruntów parafialnych i poklasztornych (te drugie miały służyć domowi księży emerytów) ${ }^{47}$. 28 sierpnia 1904 r. ks. Bresiński jako przewodniczący dozoru kościelnego zaprosił jego członków: Ludwika Hajduka, Mikołaja Mierzwę, Wincentego Nowackiego, Ludwika Szopińskiego, Nepomucena Janiszewskiego, Augustyna Myszaka (Missaka), Wojciecha Tobysa i Kazimierza Nowaka, „o 1 godzinie w południe na tutejsze probostwo celem uregulowania granic pomiędzy kościołem parafialnym a klasztorem, czyli zakładem księży emerytów" 48 .

\footnotetext{
${ }^{45}$ Akta uregulowania granic czyli separacji pomiędzy parafią oberską a zakładem ks. emerytów, Archiwum Klasztoru w Obrze (dalej: AKO), sygn. B I.12, k. 13r.

${ }^{46}$ Ks. Bresiński do Konsystorza Generalnego Poznańskiego, 12.07.1904 i 21.07.1904, AKO, B I.12, k. 9r-12v, 13v-14r.

${ }^{47}$ Notatka ks. Bresińskiego, tamże, k. 16v.

${ }^{48}$ Ks. Bresiński do członków dozoru kościelnego, 28.08.1904, tamże, k. 17r.
} 
Czynność została wykonana, dokładnie oznaczono ziemię parafialną i klasztorną, ponadto w protokole zastrzeżono dla parafian własność „krużganków procesyjnych, które się znajdują w klasztorze, [...] [oraz] prawo wchodzenia i wychodzenia do kościoła na nabożeństwa przez główne drzwi klasztorne. Również pozostać ma w dalszej posiadłości i własności parafialnego kościoła zakrystia, kapitularz i stara biblioteka"49. Od 1 kwietnia 1905 r. dochód z ogrodu i łąki przyklasztornej liczony był już do budżetu domu księży emerytów ${ }^{50}$. Część tych ziem dzierżawił proboszcz, część przekazano do użytku siostrom zakonnym. W istocie swoistą nowością, o której nie wspominały pierwsze projekty, było sprowadzenie do Obry jeszcze w 1903 r. sióstr elżbietanek, które miały służyć pracą przy domu księży emerytów. Ich przybycie wyznaczono na 30 kwietnia 1903 r. $^{51}$

Proces tworzenia instytucji objął kilka lat rozmaitych starań i zabiegów. 13 czerwca 1906 r. o kierowanie domem emerytów bp Edward Likowski poprosił obrzańskiego proboszcza, ks. Bresińskiego ${ }^{52}$. Wkrótce też pojawiły się pierwsze kłopoty związane z mieszkańcami domu, niektórzy z nich bowiem, zamiast budować własną postawą, dostarczali powodów do zmartwień. 20 października 1905 r. jeden z księży został upomniany za chorobliwe zaciąganie długów u niezamożnych wierzycieli, którzy później nie mogli się doprosić zwrotu pieniędzy. Księdzu zakazano samowolnego opuszczania murów klasztornych i przy braku poprawy zagrożono suspensą ${ }^{53}$. Ks. Bresiński odpisał słowami, które obrazują dynamizm sytuacji: „Odebrawszy rozporządzenie Wysokiej Władzy z dnia 20 października r.b. Ldz 7618/05, donoszę uniżenie, że ks. emeryt Kucharski ledwie 10 dni zabawił w Obrze, że zaproszony, jak to oświadczył, udał się 30 września r.b. do Kobylnicy, aby w tamtejszej kaplicy odprawiać nabożeństwo. Czy tam jeszcze przebywa, nie wiadomo mi" 54 . Abp Florian Stablewski z dniem 3 listopada nałożył na rezolutnego kapłana zakaz sprawowania sakramentu pokuty oraz ograniczył jego posługę wyłącznie do kościoła w Obrze. Siostry elżbietanki oraz proboszcz zostali ostrzeżeni o manii zaciągania długów przez kapłana i mieli zwracać baczną uwagę na jego poczynania ${ }^{55}$. Do Obry próbowali się dostać także kapłani kierowani przez władze kościelne na odbycie pokuty w domu księży demerytów w Osiecznej. Przełożeni reagowali natychmiast, nakazując

\footnotetext{
${ }^{49}$ Protokół czynności rozgraniczenia, Obra, 1.09.1904, tamże, k. 19r-20v.

${ }^{50}$ Bp Likowski do ks. Bresińskiego, 21.03.1905, tamże, k. 32r.

${ }^{51}$ Abp Stablewski do ks. Bresińskiego, 27.04.1903, tamże, k. 28r.

${ }^{52}$ Bp Likowski do ks. Bresińskiego, 13.06.1906, tamże, k. 55r.

${ }^{53}$ Bp Likowski do ks. Konstantego Kucharskiego, 20.10.1905, tamże, k. 57r.

${ }^{54}$ Ks. Bresiński do Konsystorza Generalnego Poznańskiego, 24.10.1905, tamże, k. 57v.

${ }^{55}$ Abp Stablewski do ks. Kucharskiego, 3.11.1905, tamże, k. 58r.
} 
właściwe miejsce zamieszkania pod karą suspensy ${ }^{56}$. Nie były to oczywiście wyłączne przypadki. Inni kapłani po prostu korzystali ze stabilizacji, jaką dawała obrzańska instytucja i spokojnie przeżywali ostatnie lata kapłańskiego życia. Wydaje się, że ostatecznie nie była to grupa zbyt liczna. Na spisie otrzymanych emerytur z 1 lutego 1910 r. widnieje tylko 6 nazwisk - ks. Gabryel, ks. Grześkiewicz, ks. Granatowicz, ks. Jaensch, ks. Kobyliński i ks. Weydmann ${ }^{57}$.

Dom księży emerytów w Obrze funkcjonował do lat dwudziestych XX w., a jego codzienność oraz skład personalny musiałby się stać przedmiotem osobnego studium. Podobnie dalszych badań domagałaby się współpraca sióstr elżbietanek z archidiecezjalną instytucją opiekuńczą, a także stosunek pruskiej administracji do idei jej utworzenia w pocysterskich zabudowaniach w Obrze. Powyższe uwagi - dotyczące zarówno 1. połowy XIX w., jak i pierwszej dekady wieku XX - miały na celu opisanie praktycznych problemów związanych z powołaniem do życia domu księży emerytów. Problemy te były dwojakiego rodzaju. Do wewnątrzkościelnej drogi rozeznania i podejmowania decyzji należały pytania o lokalizację domu księży emerytów, jego otwarcie dla duchowieństwa obu bądź tylko jednej archidiecezji, wreszcie o samą zasadność takiego instytutu i możliwość przystosowania starszych kapłanów do wymagającego regulaminu wspólnego życia. W relacjach z administracją pruską kluczową kwestią były zasady finansowania instytucji oraz jej budżet (etat). Jak niełatwe do rozwiązania były to kwestie, ilustruje fakt, iż dom księży emerytów, zaplanowany w obrzańskim klasztorze tuż po kasacie cystersów, urzeczywistniono dopiero po 70 latach.

${ }^{56}$ Ks. Goczakowski do ks. Bresińskiego, 8.09.1906, tamże, k. 65r.

${ }^{57}$ Kasa Arcybiskupstwa do ks. Bresińskiego, 1.02.1910, tamże, 87r-v. 


\section{ANEKS}

Ks. Józef Brzeziński

Uwagi nad etatem dla Domu XX. Emerytów w Obrze (1855)

AAP, OA VI 004, k.256r-261r.

\section{A. Przychód.}

Co do Przychodu nie mam nic do nadmienienia, wyjąwszy, że w tytule $17^{58}$, o tyle zmiana nastąpić musi, iż wypada w nim wykreślić nazwę dochodu z oferty czyli dzwonka i z karbony, a to z tej przyczyny, że XX. Emeryci będą odprawiali msze św. w kościele parafialnym, do którego kasy podobny dochód wpływać musi. Że zaś instytut będzie miał dochód za skóry z zabitego na mięso bydła, stąd obliczony przychód za takowe na 2 Tal. 12 śgr. 5 fen. ${ }^{59}$ będzie się mógł pozostać.

\section{B. Wydatek.}

Do tytułu I. A. nic nie mam do nadmienienia.

Do tytułu I. B. Jako w dawniejszych mych opiniach, a w szczególności z dnia 11 marca 1837 r. i z daty 19 listopada 1847, tak i teraz muszę przy mem zdaniu obstawać, że dla Instytutu XX. Emerytów jest kucharz koniecznie potrzebny. Gospodyni domu, mająca się trudzić praniem bielizny dla 20 $\mathrm{XX}$. Emerytów i inspektora, praniem bielizny stołowej, sporządzaniem tejże bielizny, pieczeniem chleba, robieniem masła i sera i w ogóle zawiadywaniem całego [256v] domowego gospodarstwa, nie będzie miała tyle czasu, aby się jeszcze gotowaniem śniadania, obiadu i kolacyi dla 29 osób, a dla chorych XX. Emerytów i częstszem sporządzaniem wyjątkowego jadła, trudnić mogła. A nawet niepodobnem jest żądać po gospodyni, aby się jeszcze trudnić miała kupnem mięsa, ryb i innych wiktuałów, po które codziennie jeździć wypada do najbliższego miasta Wolsztyna, o przeszło milę jednako od Obry odległego. Wykazuje się więc konieczna potrzeba, aby Instytut miał kucharza, który by się tem zajmował i był w stanie prócz zwyczajnych potraw, gotować i inne, jakie lekarz dla chorych przepisze. Nigdy zaś z oka spuścić nie wypada, że dom ten ma się urządzić dla kapłanów wysłużonych, godnych i tylko dla podeszłego wieku, lub jakowego kalectwa do posług parafialnych niezdatnych, a więc dla mężów do większych wygód przyzwyczajonych, których i w domu emerytów odmawiać im nie można. Zresztą mamy doświadczenia, iż dzisiaj

${ }^{58}$ Pierwotny etat zob. AAP, OA VI 004, k. 64r-73r.

${ }^{59}$ Talar (Taler, Reichstaler) $=30$ srebrnych groszy (Silbergroschen) $=360$ fenigów (Pfennigen). Zob. I. Ihnatowicz, A. Biernat, Vademecum do badań nad historia wieku XIX i XX, Warszawa 2003, s. 94. 
trudno, a czasem i niepodobno znaleźć taką kobietę, która by obok rządności w gospodarstwie domowem posiadała kwalifikację dobrej kucharki. Przypuściwszy zaś, żeby w Niemczech podobną kobietę wynaleźć się dało, to takowa zapewne z wielu względów nie odpowiedziałaby wymaganiom Instytutu.

Dla kucharza takiego rachować by potrzeba [257v] przy wolnem mieszkaniu, stole, opale itd. najmniej 60 Tal. rocznej pensyi. Także uważam za konieczną potrzebę przyjęcia do Instytutu w Obrze ogrodowego. Tamtejszy ogród jest wielki, piękny, częścią owocowy, częścią angielski, posiada przytem wiele gruntu dobrego na hodowanie warzywa. W nim więc pracować musi znający się na swej sztuce ogrodnik, który by nie tylko tenże ogród konserwował, ale go także ulepszał i dostarczał Instytutowi potrzebnego warzywa, którego wartość w Wolsztynie jest wysoka, a czasami nawet jego kupno niepodobne. Pensję dla ogrodowego wyznaczyć by potrzeba razem ze stołem, przynajmniej 140 Tal. Ponieważ zaś dla Instytutu musi się codziennie kupować w Wolsztynie albo mięso, albo ryby i inne wiktuały, także musi się dla chorych XX. Emerytów i sług sprowadzać doktora i lekarstwa, stąd wypada koniecznie utrzymywać dla niego parę koni, do których potrzebny jest woźnica, a dla niego myto, prócz stołu, przynajmniej 30 Tal. rocznie wynosić musi.

Co do Tytułu II.

W projekcie do Etatu na lata 1836 do 1838 rachowano na wyżywienie jednego x. emeryta 90 Tal. W teraźniejszym projekcie do etatu, podwyższono tę kwotę tylko o 10 Tal. rocznie, bez względu że od roku 1836 do 1855 nadzwyczaj podniosła się cena wszystkich artykułów do żywności potrzebnych. [258r] Aby rzecz lepiej wyjaśnić, muszę tutaj wyszczególnić ceny zboża i innych wiktuałów, jakie były w roku 1836, a podług których ówczasowy etat był unormowany.

Według świadectwa urzędowego magistratu miasta Grodziska z dnia 26 lutego 1837 w aktach znajdującego się, były ceny w tamtejszej okolicy przez frakcję z 12-tu miesięcy roku 1836 wzięte, następujące:

\begin{tabular}{|c|c|c|c|}
\hline & Tal. & gr. & fen. \\
\hline 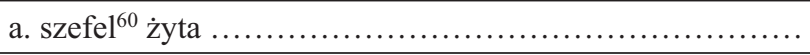 & " & 25 & $111 / 4$ \\
\hline 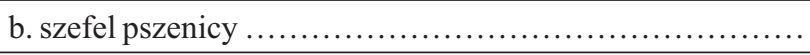 & 1 & 13 & $11 / 2$ \\
\hline c. szefel jęczmienia ......................................... & ” & 26 & $101 / 2$ \\
\hline d. grochu szefel ........................................... & 1 & 12 & 6 \\
\hline 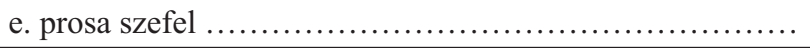 & 1 & 16 & $111 / 2$ \\
\hline f. tatarki szefel..... & 1 & 1 & $61 / 4$ \\
\hline
\end{tabular}

${ }^{60}$ Berliner Scheffel = 54,9 litra. Zob. tamże, s. 72. 


\begin{tabular}{|c|c|c|c|}
\hline & Tal. & gr. & fen. \\
\hline g. kartofli szefel ........... & , & 8 & , \\
\hline 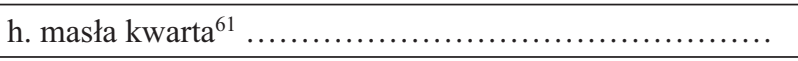 & , & 7 & 6 \\
\hline 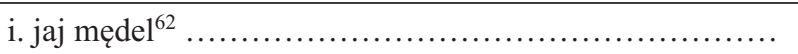 & , & 2 & , \\
\hline k. jęczmiennej kaszy kwarta ..................................... & , & 1 & 4 \\
\hline 1. tatarczej kaszy kwarta .................................. & , & 2 & , \\
\hline 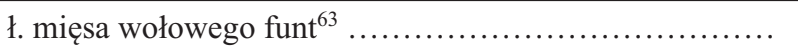 & ” & 2 & , \\
\hline 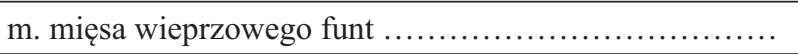 & " & 2 & 6 \\
\hline 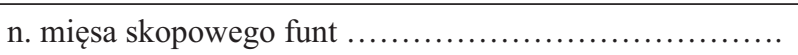 & , & 2 & , \\
\hline o. mięsa cielęcego funt ................................... & ” & 2 & 6 \\
\hline 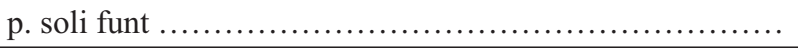 & ” & 1 & 4 \\
\hline 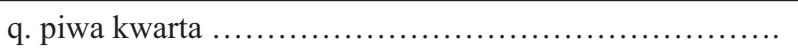 & , & , & 8 \\
\hline
\end{tabular}

Do tych cen niskich już zapewne nigdy nie przyjdzie, a ile teraźniejsze przewyższają powyższe, każdy wie, kto własny dom prowadzi. ${ }^{616263}$

$\mathrm{Z}$ tego powodu jest już dzisiaj zupełnem niepodobieństwem wyżywić, z piwem itd., [258r] jednego emeryta za 100 Tal. rocznie, czyli za 8 śr. gr. $2{ }_{3}^{2}$ fen. dziennie, ile że uwzględnić należy i to, że ci nie każdej potrawy używać mogą i że częstym podlegając chorobom, delikatniejszych i lepszych potrzebują pokarmów. Rozumiem, że zaledwo za 120 Tal. rocznie będzie można jednego x. emeryta wyżywić, mianowicie że i postne potrawy, przy wysokich cenach masła, mąki i kaszy, równie są drogie, jako mięsne. Obliczywszy więc żywienie 20 XX. Emerytów i inspektora po 120 Tal. rocznie, wypadnie w ogóle $2520 \mathrm{Tal}$. A że w projekcie do etatu obrachowano wyżywienie tych osób na 2100 Tal., stąd potrzebny dodatek 420 Tal. Do sumy projektowanej na stołowanie sług, doliczywszy kucharza i woźnicę po 60 Tal. rocznie, wypadnie większy dodatek jeszcze o 120 Tal.

Nadmienić tu także muszę, że obliczenie w projekcie do etatu dni mięsnych na 295, a postnych tylko na 70 jest niewłaściwe i bardziej by się zastosować dało do wrocławskiej, niż do poznańskiej diecezji. Porachowawszy tylko piątki i soboty jako dnie postne, już wypada liczba dni postnych 104, doliczywszy zaś wielki post czterdziestodniowy, suche dni, krzyżowe, wigilie itd., wypadnie u nas przeszło 150 dni postnych. [258v] Że jednak w projekcie do etatu nie są obliczone osobne ceny na dni mięsne i na dni postne, tylko ryczałtem oznaczono cenę na wyżywienie roczne jednego x. emeryta po 90 Tal., stąd

\footnotetext{
${ }^{61}$ Berliner Quart $=1,1$ litra. Zob. tamże.

${ }^{62}$ Mendel $=15$ sztuk. Tamże, s. 79.

${ }^{63}$ Funt pruski $=0,46$ kg. Tamże, s. 80 .
} 
obliczenie dni mięsnych i postnych nie jest potrzebne i może bydź całkiem opuszczone.

Co do Tytułu III.

Suma przeznaczona na ubiór dla XX. Emerytów jest także za nisko obliczona. Każdy z XX. Emerytów będzie potrzebował:

1. Rewerendy na rok jeden ta kosztuje: 5 łokci ${ }^{64}$ sukna à $2 \mathrm{Tal}=10 \mathrm{Tal}$.

podszewka, guziki i robota -2-15, razem 12 Tal. 15 śgr.

2. Spodnie jedne rocznie te kosztują: 2 łokcie sukna à $1 \frac{1}{2}$ Tal. $=3$ Tal. robota i podszewka 1 [Tal.] 4 [śgr.]

3. Westkę jedną rocznie - 1 [śgr.]

4. Kaftanik rocznie jeden, kosztujący 2 [śgr.]

5. Jedne buty nowe na 3 lata à 4 Tal., wypada rocznie 1 Tal. 10 śgr., jedno podszycie rocznie 2 [Tal.], jedno podzelowanie 20 [śgr.], [razem] 4 [Tal.]

Zważając, że starzy pociągając nogi po ziemi więcej butów zedrą, suma ta nie jest za wielka.

6. Kalosze na dwie zimy, kosztujące 2 Tal., a więc na rok jeden wypadnie 1 [Tal.]

7. Kapelusz na dwa lata za 2 Tal. 20 śgr., a więc rocznie 1 [Tal.] 20 [śgr.]

8. Czapkę na dwie zimy za 2 Tal., rocznie więc 1 [Tal.] [259r] Do przeniesienia [na drugą stronę obliczeń]: 26 Tal. 25 śgr.

9. płaszcz na 3 lata.

Ten kosztuje 6 łokci sukna à 1 Tal. 10 śgr. $=8$ Tal.

Wata, podszewka i robota -4 [Tal.]

Razem 12 Tal.

Na rok więc wypadnie 4 [Tal.]

10. Chustek do nosa 12 na dwa lata à 6 śgr. $=2$ Tal. 12 śgr.

Na rok więc wypadnie 1 [Tal.] 6 [śgr.]

11. Chustkę na szyję, jedwabną, czarną na rok à 1 [Tal.] 10 [śgr.]

12. Koszul 6 na dwa lata à $1 \mathrm{Tal}=6$ Tal., rocznie więc 3 [Tal.]

13. Gatek troje na rok

1 para kosztuje 5 łokci parchanu à 5 śgr. $=25$ śgr.

Za robotę i guziki - 10 [śgr.], razem 1 Tal 5 śgr.

A więc za 3 pary 3 [Tal.] 15 [śgr.]

${ }^{64}$ Berliner Elle $=0,6$ m. Zob. tamże, s. 72. 
14. Szkarpetek rocznie 6 par à 8 śr.gr. [razem] 1 [Tal.] 18 [śgr.]

15. Szlafmyc 3 na rok à 10 śr.gr. [razem] 1 [Tal.]

16. Piuski dwie na rok à 10 śr.gr. [razem] 20 [śgr.]

17. Pantofle na 3 lata za 1 Tal., wypadnie rocznie 10 [śgr.]

18. Szlafrok na dwa lata za 4 Tal., wypadnie rocznie 2 [Tal.]

Suma rocznego wydatku na odzież - 45 Tal. 14 śr.gr. Zważając przecież, że każdy z XX. Emerytów wniesie coś z ubioru do instytutu, rozumiem, że można by przez przecięcie przyjąć roczną kwotę na oporządzenie jednego x. emeryta na 30 Tal., tyle właśnie, ile obliczono w etacie domu XX. Emerytów dla diecezyi chełmińskiej.

Podług tego rachunku na 1 emeryta 30 Tal. wypadnie, na 20 XX. Emerytów 600 Tal., a że w projekcie do etatu obliczono na ubiór rocznie 200 Tal., potrzeba więc dodatku 400 Tal. [259v]

Już w projekcie do etatu roku 1836 przyjęto, że na ogrzewanie mieszkania dla XX. Emerytów potrzeba rocznie przez przecięcie po 5 sążni drzewa twardego. Rozumiem, że ta ilość jest koniecznie potrzebna, zważając, że starcy muszą mieć ciepło w pokojach i że w dniach mroźnych po dwa razy w piecu dobrze palić potrzeba.

Rachując więc dla 20 emerytów twardego drzewa po 5 sążni, wypadnie rocznie 100.

Dla inspektora kilku pokoi - 10; dla gospodyni i sług żeńskich - 4; dla kucharza - 4; dla fortiana - 4; dla hausknechtów i furmana - 4; dla ogrodowego - 4; do prasowania bielizny i pieczenia opłatków -2 . Wypadnie rocznie twardego drzewa 132 sążni6 ${ }^{65}$, rachując zaś sążeń jako w projekcie do etatu po $6{ }^{2} / 3$ Tal., wypadnie za 132 sążni 880 Tal. A że w projekcie do etatu obliczono twarde drzewo na 400 [Tal.], potrzeba zatem dodatku $480 \mathrm{Tal}$.

Na kuchnią i do prania, uważam, że 20 sążni drzewa miękkiego wystarczą.

Pozycje do Tytułu V i VI uważam za dostateczne.

Do Tytułu VII uważam potrzebę dodać, co następuje:

Ponieważ XX. Emeryci będą odprawiali msze św. w kościele parafialnym i do ubrania się potrzebują pomocy sługi [260r] kościelnego, który także nad aparatami i bielizną kościelną instytutową musi mieć dozór, przeto wypadałoby mu dadź za to wynagrodzenie, które uważam za dostateczne, gdy otrzyma 30 Tal. rocznie.

Także muszą mieć XX. Emeryci przynajmniej dwóch chłopców do posługi przy mszach św. (ministrantów), dla których przynajmniej 24 Tal. rocznie przeznaczyć należy.

Tym sposobem przybyłoby do tego tytułu 54 Tal.

${ }^{65}$ Sążeń = ok. 1,7 m. Zob. tamże, s. 82. 
Do Tytułu X.

Fundusz ten 500 Tal. przeznaczony jest nie tylko na XX. Emerytów, ale i na wspieranie $\mathrm{xx}$. ubogich in cura animarum pracujących. $\mathrm{Z}$ tego powodu stosownie do pierwiastkowego przeznaczenia tego funduszu, najwięcej na etat XX. Emerytów, 250 Tal. zarachować można.

Te zaś pieniądze nie wystarczą na różne jeszcze pozostałe potrzeby XX. Emerytów, projektem do etatu nie objęte, a w szczególności

a) na tabakę i inne drobne potrzeby wypada oddać do rąk XX. Emerytów, przynajmniej po 2 Tal. miesięcznie.

Wydatek ten koniecznie jest potrzebny, gdy się zważy, że dla przyjęcia krewnych, przybywających w odwiedziny do XX. Emerytów żadnego nie masz funduszu, ani też nie przeznaczono funduszu na koszta podróży, gdyby XX. Emeryci w interesach swoich musieli jakowe podejmować. [260v]

b) wypada także dadź XX. Emerytom w dni uroczystsze po kieliszku wina, a w szczególności:

1. w Wigilię Bożego Narodzenia, 2. w Wigilię Nowego Roku, 3. w Wielki Czwartek, 4. na Wielkanoc, 5. w Zielone Świątki, 6. w Boże Ciało, 7. w Uroczystość Śś. Apostołów Piotra i Pawła i 8. w dniu Urodzin Najjaśniejszego Króla JMCi. W dniach tych dawszy podczas obiadu każdemu z XX. Emerytów po pół butelki wina, wypadnie na jednego rocznie 4 butelki, na $20 \mathrm{XX}$. Emerytów więc 80 butelek rocznie, butelkę rachując po 20 śgr. wypadnie razem 53 Tal. 10 śgr. Że zaś na ten tytuł będzie funduszu 250 Tal., a wydatki będą wynosić ad a) 480 Tal., ad b) 53 [Tal.] 10 śgr. = 533 Tal. 10 śgr., potrzeba więc do tego tytułu dodatku 283 Tal. 10 śgr.

Dodać także należy do etatu wydatkowego na utrzymanie 2 koni i 4 krów, które są koniecznie potrzebne dla instytutu, przynajmniej 300 Tal. rocznie.

Musi także bydź w etacie umieszczona suma roczna na reparację domu instytutowego i budynków gospodarczych, na co przynajmniej rocznie 300 Tal. przeznaczyć należy.

Koszta pogrzebów zmarłych XX. Emerytów mogą bydź z funduszu ad extraordinaria $\mathrm{z}$ tytułu XI pokryte. [261r]

Obliczywszy według powyższych uwag wykazane potrzebne dodatki do etatu wydatkowego [... ${ }^{66}$ wypadnie powiększyć etat wydatkowy o 2587,10.

W Poznaniu dnia 4 grudnia 1855

X. Brzeziński

${ }^{66}$ Następuje ponowne podsumowanie dodatków pieniężnych, które zostały już raz omówione szczegółowo powyżej. 


\title{
ON THE PLANS OF ORGANIZING A HOME FOR RETIRED PRIESTS IN A POST-CISTERICIAN MONASTERY IN OBRA (1836-1906)
}

\begin{abstract}
Summary
The responsibilities of diocesan bishops have always included the care of elderly and ill priests who did not have sufficient means of maintenance after retiring from active ministry. In the diocese of Poznan the caring institutions for priests have been evidenced since the $15^{\text {th }}$ century. The bull De salute animarum of 1821 asserts that the Prussian state takes upon itself the maintenance of homes for retired priests. After the dissolution of the Cistercian monastery in Obra at the turn of 1835 and 1836, Archbishop Marcin Dunin planned to use the existing buildings for the needs of care of the elderly priests. However, the then prepared Statues and budget were not put into practice and the institution planned in 1836 began to function only seventy years later. The article describes the discussions around Archbishop Dunin's plans and the financial aspects of this ecclesiastical caring institution for priests.

Słowa kluczowe: Dom księży emerytów, archidiecezja gnieźnieńska i poznańska, wieś Obra, kasata, Wielkie Księstwo Poznańskie, abp Marcin Dunin, miary i wagi

Key words: Home for retired priests; archdiocese of Gniezno and Poznań; village of Obra; dissolution of monastery; Grand Duchy of Poznań; Archbishop Marcin Dunin; weights and measure
\end{abstract}

\section{BIBLIOGRAFIA}

\section{ŹRÓDŁA ARCHIWALNE I DRUKOWANE}

\section{Archiwum Archidiecezjalne w Poznaniu}

Akta Arcybiskupie - Księża Emeryci i demeryci: urządzenie domu dla nich, 1835-1866, sygn. OA VI 004.

\section{Archiwum Klasztoru w Obrze}

Akta uregulowania granic czyli separacji pomiędzy parafią oberską a zakładem ks. emerytów, sygn. B I.12.

Synodus dioecesana posnaniensis sub Illustrissimo ac Reverendissimo Domino D. Christophoro Szembek, Dei et Apostolicae Sedis Gratia Episcopo Posnaniensi, nominato Vladislaviensi, Abbate Commendatario Clare Turbae per biduum Varsaviae in Insigni Ecclesia Collegiata S. Joannis Baptistae Celebrata A.D. MDCCXX Diebus 27 et 28 Mensis Februarii, Varsaviae, Typis S.R.M. Scholarum Piarum.

\section{OPRACOWANIA}

Hozakowski W., Arcybiskup Dunin a Liceum Teologiczne, „Kronika Miasta Poznania”, 1923, nr 12, s. 222-236. 
Ihnatowicz I., Biernat A., Vademecum do badań nad historia wieku XIX i XX, Warszawa 2003.

Józefczyk M., Translacja bulli „,De salute animarum” i dokumentów korygujących granice diecezji warmińskiej w 1861 i 1922 roku, ,Studia Elbląskie” 18 (2017), s. 9-35.

Kopiczko A., Reorganizacja Kościoła katolickiego w Prusach na podstawie bulli „,De salute animarum”, „Kościół w Polsce. Dzieje i Kultura” 12 (2013), s. 65-84.

Neumann P.F., Starania arcybiskupa Marcina Dunina i Edwarda Raczyńskiego o przywrócenie klasztorów $w$ archidiecezjach gnieźnieńskiej i poznańskiej, „Ecclesia. Studia z Dziejów Wielkopolski" 2 (2006), s. 221-247.

Nowacki J., Archidiecezja poznańska w granicach historycznych i jej ustrój, t. 2, Poznań 1964.

Nowacki J., Piechnik L., Hozakowski W., Dzieje Seminarium Duchownego w Poznaniu w latach 1564-1939, Poznań 2006.

Nowacki J., Synody diecezji poznańskiej w latach 1252-1738, Poznań 2004.

Paprocki F., Wielkie Księstwo Poznańskie w okresie rząów Flottwella, 1830-1841, Poznań 1994.

Sawicki J., Synody diecezji poznańskiej i ich statuty, Poznań 1952.

Stownik geograficzny Królestwa Polskiego i innych krajów slowiańskich, red. F. Sulimierski, B. Chlebowski, W. Walewski, t. II, Warszawa 1881.

Zając P., Uposażenie parafii obrzańskiej i wybrane aspekty działalności duszpasterskiej w okresie pocysterskim w latach 1836-1861, „Ecclesia. Studia z Dziejów Wielkopolski” 8 (2013), s. 167 -205 . 